\title{
States, Institutions, and Literacy Rates in Early-Modern Western Europe
}

\author{
Tyrel C. Eskelson ${ }^{1}$ \\ ${ }^{1}$ Faculty of Education, Hokkaido University, Sapporo, Japan \\ Correspondence: Tyrel C. Eskelson, Faculty of Education, Hokkaido University, Sapporo, Japan. E-mail: \\ tycameroneskelson@hotmail.ca
}

Received: January 25, $2021 \quad$ Accepted: February 28, $2021 \quad$ Online Published: March 3, 2021
doi:10.5539/jel.v10n2p109

\begin{abstract}
The purpose of the paper is to develop the theory that structural or procedural changes in institutions precede changes in education in a society. It examines the development of pre-modern institutions in Western Europe in the 16th and 17th centuries and the influences this had on growth in literacy rates within these states. Literacy rates in Western European countries during the Middle Ages were below twenty percent of the population. For most countries, literacy rates did not experience significant increases until the Enlightenment and industrialization. Two early exceptions to this broad trend were the Netherlands and England, which had achieved literacy rates above fifty percent of their populations by the mid-seventeenth century. The explanations for these divergent trends are the structural changes in formal institutions that embodied capital markets, protected private property, and overall established the initial steps in developing modern political institutions. This created incentives to invest more in schools per capita as well as incentives for a middle class to invest more in literacy and numeracy skills for a market-exchange economy that was becoming more specialized in division of labor.
\end{abstract}

Keywords: commerce, Dutch Golden Age, early-modern Europe, education, England, institutions, literacy, little divergence

\section{Introduction}

This paper examines the historic relationship between the institutions of a society and education, and develops the argument that structural or procedural changes in institutions precede changes in education. The specific argument is that in the early-modern period between 1500 and 1700, literacy rates in the Netherlands and England experienced divergent growth from the rest of Western Europe due to their preceding establishment of more inclusive and efficient institutions. Such institutions allowed for a society with structure and rules that better integrated markets, led to the growth of towns and cities, had better fiscal management, and created better incentives for families to invest in formal education for their children.

The main measure of change considered is the growth in estimated literacy rates within early-modern Western European societies. Literacy rates serve as a useful measure of formal education within a society because reading and writing require direct instructional guidance to transmit evolutionarily novel skills. Estimates of historical literacy rates before compulsory schooling remain imprecise due to insufficient data. One method derives estimates of literacy from the proportion of people who could sign their marriage certificates. Another more recent method is to measure book production and accumulation to reflect the demand for books by the proportion of society that is literate. Though imprecise, these methods have provided basic historic trends in the spread of literacy throughout Western European populations between 1500 and 1700. The limitation of this analysis is that it does not capture the variation in literate abilities, for example between a shop owner who can sign his name and Thomas Aquinas. Accounting for limitations, estimated literacy rates still provide a useful way to analyze the historic growth of formal education within a society. Education is defined as the skills and knowledge acquisition that children and adults acquire to better compete and cooperate within their society. Formal education is conceptualized as goal-directed instruction of evolutionarily novel concepts, skills, and abstract ideas. This definition encompasses any learning related to literacy, numeracy, scientific concept change, abstract rules and ideas, and certain forms of human coordination such as military training or using time to order society (Carey, 2000; Geary, 2007; Lancy, 2010, 2012, 2016; Eskelson, 2020). This paper uses these conceptualizations 
to analyze early-modern Europe.

Research on Medieval and early-modern European literacy rates has made progress in the past forty years (Allen, 2003; Houston, 1988). The most recent techniques of converting figures of per capita book consumption into estimates of literacy percentages per population from the Middle Ages to the Industrial Revolution has provided great insight into the trends of literacy growth throughout this period (Buringh \& Van Zanden, 2009). Other studies that examine the Protestant Reformation (M. Weber, 1930; MacCullough, 2003); economic growth (Acemoglu, Johnson, \& Robinson, 2005; North \& Thomas, 1973; De Vries \& Van der Woude, 1997; De Pleijit \& Van Zanden, 2016; Maddison, 2003); development of world trade (Findlay \& O'Rourke, 2007); the social and political aspects of state-building (Elias, 1978; Ertman, 1997; Fukuyama, 2011; Lachmann, 1987, Strayer, 1970; Tilly, 1985); and demographic change (Dodgshon \& Butlin, 1978), have added to a growing understanding of the variables and conditions that led to the development of capitalism, the Scientific Revolution, the Enlightenment, and the Industrial Revolution. All of these different perspectives help to better understand the development of education throughout this period.

Past historical research on early-modern European education are mainly works of social history that describe trends such as the development of schools, philosophy, and pedagogy (Armytage, 1964; Bowen, 1975, 1981; Durkheim, 2006; Jewell, 1998; Lawson \& Silver, 1973; Maynes, 1985; O’Day, 1982; Spufford, 1995; Stephens, 1990). These works have provided excellent contributions to our understanding of early-modern education. Within these works, there are brief analyses on why education grows within a society. Houston (1988, p. 5), for example, wrote that "Education and literacy...were themselves dependent on the societies in which they grew and can thus be treated both as agents of change and as indicators or even products of social developments." For the most part, however, the focus is on what occurs in educational development rather than on why it occurs. Analysis of why formal education grew in early-modern Europe would be challenging without the excellent research of the aforementioned scholars.

The historical trends of education in Europe from the sixteenth century to the late-eighteenth century show major growth and expansion of schooling, vocational training, and higher education. This occurred as part of the growth in populations, market economies, cities, and world trade. The number of explanatory variables impacting this phenomenon make this a challenging endeavor, and due to the scarcity of data, will remain open in the future to fresh inquiries.

In the late sixteenth century, the Netherlands and England began experiencing a divergence from the rest of Western Europe in social, political, and economic development known as the "little divergence" (De Pleijit \& Van Zandan, 2016). Estimates of literacy rates also show a little divergence during this period. One hypothesis for this rise is the impact of movable-type printing technology. Throughout the sixteenth century book production increased and the cost of books decreased, making books more accessible and affordable to the general public, thus improving the incentives to become literate. While printing press technology had major effects on the spread of information throughout European society, the Protestant Reformation (Ferguson, 2018) and double-entry bookkeeping (Gleeson-White, 2011) among the most influential, it cannot account for disparate growth in literacy rates among societies that shared this technology. Demand for books in a thriving book market does however demonstrate a culture that had already placed a high value on literacy and reading.

A second hypothesis for diverging literacy rates is the religious division that occurred following the Protestant Reformation. One of the tenets of Protestantism and Calvinism more specifically was that it differed from the Catholic tradition in encouraging people to read the bible for themselves. M. Weber's (1904-1905) classic essay linked Calvinist Protestantism to the development of a new ethos that praised hard work, honest business, and prudent personal finance; all central to modern capitalism. Entangled within this hypothesis is the dissolution of the monasteries, which uprooted centuries of Catholic institutional tradition and transferred that wealth and power, first to monarchs, but within a few decades it ended in the hands of private owners who bought and sold it in an accelerating land market.

In terms of literacy attainment in Protestant Europe, by the end of the seventeenth century, England and the Netherlands are the only two countries that experience significant growth during this period. Sweden matches this by the end of the eighteenth century. Literacy in Germany, however, does not grow as comparatively well as the Netherlands or England. By the end of the seventeenth century, literacy rates in Germany are close to the average for Western Europe and are similar in proportion to Catholic France. The dissolution of the monasteries and the Protestant Reformation had a major impact on Western Europe, but it is an incomplete hypothesis to explain disparate growth in literacy rates. A complete explanation of comparative differences requires analysis of the institutional traditions that created particular structures, rules, incentives, and social solidarity within these 
societies.

The relationship between institutional development and growth in education is a topic that needs more analysis because it works for any variation of society in human history. New Institutional Economics has developed a large body of research demonstrating the relationship between formal and informal institutions and economic growth (Acemoglu, Johnson, \& Robinson, 2005; North, 1973, 1981, 1990, 2005). From this perspective, developments in innovation, economies of scale, capital accumulation, and education "are not causes of growth; they are growth" (North \& Thomas, 1973, p. 2). It follows from this perspective that historical growth in formal education will result from the structural development of more inclusive and efficient institutions. The next section will develop this relationship further.

\section{Institutions and Education}

The relationship between education and institutions, both formal and informal, is an area that will benefit from more research. A comparative approach, for example, that examines the strengths of developed versus developing states in the twenty-first century centers around each respective state's progress in establishing modern political institutions. A strong centralized state, rule of law that protects liberty and property, and accountability in business and government will influence a society's levels of violence (Pinker, 2011), trust (Fukuyama, 1995), corruption, competitiveness, and educational outcomes, among many other variables. Countries in the twenty-first century that have historically developed these modern political institutions, for example Denmark or Japan, also produce excellent results in educating their populations. A better understanding of the historic relationship between these two aspects of society has enormous future potential for analyzing education.

Institutions regulate a society's needs for shelter, sex, security, and sustenance in a world with uncertain or ambiguous futures. Regarding education, they provide the structure, rules, and incentives for how people learn to compete and cooperate. That is, they influence what rules, norms, conventions, and social behaviors children will learn to become members of their society. The degree to which these institutions help reduce future uncertainty will determine their import as valuable transmissions to the next generation. Institutions arise from human nature and a complex interplay of many variables: geographic endowment; threat levels from nature, weather, or other societies; modes of energy capture (Morris, 2011); the scale of social organization, etc.

Institutions can be divided into informal and formal. The informal institutional framework of a society involves the encoded knowledge and beliefs that govern exchange, cooperation, and culturally important stories, rituals, and moral codes. The foundation for this is a human universal yet their expression varies across different societies. Formal institutions, on the other hand, are extensions of state-level societies that develop a hierarchical structure to maintain order and functioning throughout. Both have a direct relationship to education in a society.

Past research has shown how the emergence of ancient civilizations and the subsequent development of formal institutions, such as state, law, and military institutions, led to the development of new accounting and bookkeeping techniques, religious beliefs that cohered society together, and written language that represented the spoken word. In ancient Mesopotamia, Egypt, China, and Mesoamerica, the development of formal institutions in these pristine emergent societies required scribes for accounting and bureaucratic purposes. This led to the creation of formal education to pass literacy and numeracy skills on to the next generation of administrators. (Eskelson, 2020). Historically, the structure of formal institutions, specifically the bureaucracy, administrations, and legal systems of states, as well as religious or spiritual institutions, have had a direct relationship to what formal education is needed in a society.

Historical analysis of education provides an understanding of how past societies lived, thought, and passed their skills and knowledge to the next generation. How past societies raised children is indicative of their thoughts on human nature, what skills were necessary for survival, and how they dealt with the common experiences of suffering, competition, and cooperation. Education is a reflection of a society and its unique formal and informal institutional development over time.

Before the development of state societies, band and tribal scales of social organization cohered around kinship groups and informal institutions. Both presently, and in the past, there was no formal education in these types of societies. State societies developed at different periods throughout the past five thousand years. In Europe, after the collapse of the Roman Empire, states of the Middle Ages were weak and decentralized, existing in system of feudal contracts between monarch, wealthy lords, and peasants. The importance of the Catholic Church influenced the development of states so that, instead of state building from a kaleidoscope of kinship groups, European monarchs developed states out of communities that cohered around Christianity. The roots of individualism in European society developed from this phenomena (MacFarlane, 1978; Fukuyama, 2011). 
The period of centralized state building between the eleventh century and the sixteenth century required mounting a governance structure replete with educated bureaucrats throughout a specified territory. In England, for example, the period between the eleventh and the fourteenth century has been described by Clanchy (1979) as a transition From Memory to Written Record, or in other words the increased use of formally educated people to work in the bureaucracies and administration of the state. Likewise, in England, the transition from itinerant court to a state-wide legal system required the training of judges and lawyers who had studied precedent in the emerging Common Law (Fukuyama, 2011).

The three institutions of the Catholic Church, centralized state, and legal system were the focus of university training in the Middle Ages. Between the fall of the Roman Empire and early-modern Europe, these three institutions provided the incentives for a formal education. The economies of Western Europe remained agrarian, with a majority of the populations engaged in self-subsistence agriculture. For most people in these societies, investing in a formal education was either unattainable, inconceivable, or the cost simply far outweighed the benefit. Furthermore, some children during this period did receive some formal schooling, but without the proper opportunities in society to utilize literacy and numeracy, these skills were quickly forgotten. In this world, children became an economic asset as soon as they were able. Any time spent in formal education was an economic liability that most families in the Middle Ages could not afford. The low literacy rates in states of the Middle Ages reflect the nature of their economies, security threats, and the type of institutions that best suited their survival.

Growth in literacy, and formal education more generally, proceeded with the needs of state building and its bureaucracies. Through the process of building the institutions of government, bureaucracies, and legal systems, states increased their use of written documents and archives, which further influenced the selection of candidates to work in the state and legal system. But this was a gradual development. Maitland observed of the Medieval period, in comparison to how modern states rely on the written word, "that we have almost forgotten how much of the world's business, even in communities by no means barbarous, has been carried on without it" (Pollack \& Maitland, 1952, p. 25).

The development of the state and legal governance structures also had important influences on violence and codes of etiquette. Elias (1978) described this as a Civilizing Process whereby after a rule of law developed, wealthy powerful landowners increasingly relied less on private armies to acquire territories, and instead spent more time at court vying for influence with the monarch. The codes of conduct at court inculcated new practices in how nobles behaved, and raised their children to behave. Over time, these courtly practices of etiquette permeated throughout large sections of society. The development of literacy in European states follows an analogous path. Literacy, beyond monasteries and church institutions, first developed as a prerogative of the state, then spread throughout the noble and aristocratic classes during the Renaissance. The development of the rule of law and protection of property rights meant that wealthy landowners sent their children to institutions, like the Inns of Court, to study law so they could better understand the rules and their rights as landowners. As middle-classes expanded, literacy and gentlemen codes of etiquette trickled down into that strata of society.

The states of early-modern Western Europe are the first states in history to experience significant growth in literacy rates per population, yet the timings of these increases were different in each state. Prior to the seventeenth century, all states in Western Europe exhibit literacy rates close to the average of eighteen percent. During the seventeenth century, most Western European countries experience increases in literacy rates, yet only two experience significant growth above the average rate of 25 percent: The Netherlands and England, both of whom increased their literacy rates to 53 percent of their populations. Other Western European countries, such as France, Spain, Germany, Portugal, and Italy experienced average or below average growth in literacy rates throughout these centuries, never approaching half their populations (Buringh \& Van Zanden, 2009). These divergent developments in literacy present a challenging but valuable opportunity to identify the reasons why different countries in Western Europe experienced different outcomes.

The next section of this paper will provide historical evidence to support the argument that differences in institutional traditions led to different outcomes in formal education in Western Europe. More extractive institutions produced less market integration and more market regulation, less social mobility, and overall less incentives for wider segments of the population to invest in formal education for their children. More inclusive institutions, by comparison, led to better integrated market economies, more social mobility, and a rise in market towns and cities supplied by better cultivation of lands. With better incentives, more families invested in formal education for their children. Likewise, those who had benefited from this growth in access to markets and better opportunities were eager to establish schools to train the next generation in useful skills for their trades. The following section will compare two examples of extractive institutions, Spain and France, with two examples of 
more inclusive institutions, the Netherlands and England.

\section{Spain and The Netherlands}

Western European state formation occurred through the eleventh to fifteenth centuries. Heavy geopolitical competition and state instability required increasing growth in military, administrative, and fiscal capabilities (Ertman, 1997; Fukuyama, 2011). In Spain's case, by the end of the fifteenth century, the government of Castile had extended their control across much of the Iberian Peninsula. The marriage between Ferdinand of Aragon and Isabella of Castile united two important but different regions of the Iberian Peninsula in the mid-fifteenth century. As Elliott has stated, the union "determined that Castile should be head of the empire" (Elliott, 1955, p. 258), which had important consequences for which institutional traditions would accompany its expansion into the New World.

The full expansion of the Spanish state's monopoly on power, and extension of its legal system throughout the Iberian Peninsula, played an important role in reducing internal violence. On the whole, throughout the sixteenth century, internal violence in European nation states was on the decline (Eisner, 2003; Elias, 1978; Pinker, 2011). This phenomenon represents an interesting look at how formal justice systems supersede informal institution of justice, and how long and challenging a process it is for this to become a cultural and political tradition. In oral cultures the traditional method of adjudicating disputes over land and family honor was done at the local level through feuding and dueling between kinship groups. In most cases, formal legal systems required the nobility to adopt it first before it became accepted in society.

The Catalan Francisco de Gilabert, writing in the early seventeenth century, argued that the nobility was slow to adapt the methods of the rule of law because "they are brought up without religious instruction or letters," and instead learn "only how to use a pistol" (Casey, 1999, p. 172). The focus on restraint and self-control, rather than on the traditional codes of honor and violence that went hand in hand, was characterized by Hirschman (1977) as a more pronounced social and cultural focus on interest over passion. The Spanish writer and tutor Diego Gurrea recognized the need for better education in self-control as a necessary feature of citizenship. In an education handbook of 1627, he argued that the nobility of Spain needed to become more familiarized with hard work and learn self-discipline as means to control one's passions. (Casey, 1999, p. 221). There were other institutional factors that shaped attitudes toward education in the Spanish Empire.

Spanish monarchs, beginning with Charles $\mathrm{V}$ in the early sixteenth century, eroded representative institutions such as the Cortes's right to approve new taxes, and in effect, extended their legislative powers throughout the realm. The Habsburg rulers involved the Spanish Empire in a series on geopolitical struggles to pursue hegemonic power on the continent and overseas, but without the consent of representative bodies such as the Cortes, found themselves in perpetual need of revenue. Two sources of income served as impediments to necessary fiscal reform: revenue gained from colonies in the New World and the sale of public officeholding as private property. Between the mid-sixteenth and mid-seventeenth century, the sale of offices in administration occurred until "there was essentially one officeholder for every 166 inhabitants" (Ertman, 1997, p. 119). The development of venal officeholding also had important effects on how education developed during the Spanish Empire's rise to hegemonic power between 1500 and 1650.

In several respects, education in early-modern Spain bears many resemblances to other nations on the continent. The family was the primary source of education, and after the age of six, childhood was finished and the father made a decision about the best path for the child's future. Children of the aristocracy had the options of primary schools, tutors, and Latin grammar schools. More printed books and a blossoming literature tradition created more interest in becoming literate, but this interest did not spread much below the nobility. Throughout the sixteenth and seventeenth centuries there was still little incentive for the masses to invest in literacy. "Economically, its value was limited, and though it might offer some protection against forged documents, literacy was not worth the time, trouble, and expense it took to acquire (Kagan, 1974, p. 18). More widespread literacy within Spanish society was not worth the time to acquire because the institutional tradition of venal officeholding, served simultaneously to restrict and misguide the incentives to invest in formal education.

Spain's rise in the sixteenth century developed need for formally educated people to fill its expanding bureaucratic posts, and graduates sought after these posts because they were one of the few opportunities to be accepted in the high culture of upper-class society. The institutional tradition of patrimonialism in bureaucracy (Ertman, 1997; Fukuyama, 2011; M. Weber, 2019) created incentives for the wealthy, and the aspiring wealthy, to invest in officeholding rather than trade or business. Spain's population grew by roughly two million people during the sixteenth century, yet more wealth in the region did not generate dynamic growth in the overall economy. Nor did the growth in wealth develop novel incentives in society for new generations to invest in 
literacy or formal education (Casey, 1999, p. 21).

Those who did become formally educated sought public office positions and the social prestige that came with working among the nobility, and furthermore, the chance to share their contempt for commerce and manual labor. But because this route offered the best opportunities in society, the amount of graduates soon outnumbered the available positions. Graduates preferred to wait for a position to open rather than apply their skills to another trade. As in France, a large chasm opened between the masses of poor and the wealthy upper-classes in society, with very few in between working hard to join the latter in social prestige. Contemporaries of the time noted the lack of fiscal responsibility and social solidarity that slowly eroded the Empire's status as a major power in Europe. Some, such as Saavedra Fajardo, even argued that Spain's social and economic problems were due to too much schooling, which encouraged youth to abandon other productive fields for the chance at working for an officeholder (Kagan, 1974, p. 21). The Spanish Empire did not have too much education; instead, they had too few social and economic incentives to invest in a formal education and too few avenues that would make it useful.

The institutional development of the Spanish Empire was the reason it did not experience sustained growth. By the middle of the seventeenth century, degeneration and decay had set in because the governance structures failed to adjust to the growing economic problems and decline in revenue from New World colonies. Education, too, had failed to develop much beyond the nobility in Spain. Allen (2003) estimated that literacy rates in Spain by the end of the eighteenth century were roughly twenty percent. More recent measures of production and demand for books has revised this figure down to just eight percent of the population (Buringh \& Van Zanden, 2009). Spain had emerged from the Middle Ages as one of Europe's most powerful and richest empires, yet important segments of their state and society failed to develop along paths that could produce sustained economic growth. The perpetual fiscal problems of the state, and the exemption of nobility from paying taxes, meant the poor of Spain endured the burdens of a consistently near-bankrupt empire. The failure to develop a more literate culture during the early-modern period is connected to the institutional development that perpetuated venal officeholding, while concurrently failing to expand the state's economic integration of markets. Towards the end of the sixteenth century Spain's wealthiest continental territory, the Netherlands, revolted against the empire and achieved independence. The contrast in institutional development in the Dutch Republic produced major disparities in wealth and human capital.

The Dutch Revolt in the late sixteenth century resulted in the replacement of Antwerp with Amsterdam as the major commercial trading hub of Atlantic Europe, and the creation of the Republic of Dutch United Provinces. Though no strong centralized state formed in the Dutch Republic, the region in the seventeenth century achieved a high level of economic integration. From the work of communal institutions over the previous two centuries, the Dutch had transformed their low lying, rather difficult terrain into a network of navigable rivers and canals, well-connected cities of commerce, and a specialized rural sector that produced goods for sale in the international market. As in other Western European states throughout the sixteenth century, the Netherlands territories experienced significant population growth that occurred in both urban and rural settings. The trend of urban population growth grew until the late seventeenth century, reaching a peak of nearly half the country living in cities (De Vries \& Van Der Woude, 1997, pp. 63, 80). These features of Dutch society help explain why literacy rates steadily grew.

It was not just the Protestant Reformation that shifted people's attitudes towards becoming literate so that they could read the bible for themselves. The above-mentioned features of urbanization and commerce had already achieved high literacy rates in centers such as Amsterdam. In 1583, 55 percent of men and 38 percent of women were literate (De Vries \& Van Der Woude, 1997, p. 170). In the Netherlands, as happened in England throughout much of the sixteenth century, what was just as significant as the new Protestant ethos was the dissolution of the Catholic Church institution that had held a major role in society as landowners and educators, among many other things. The Reformation transferred land within cities and throughout the countryside to private owners, helped absorb a growing population, and in several cases, former churches became schools. Nevertheless, the growing trend in Dutch literacy was more due to expanding commerce and traditions of inclusive institutions that were present long before religious reforms. It was these institutions that shaped the flourishing of the early seventeenth century; a period now known as the Dutch Golden Age.

By the middle of the seventeenth century, the Netherlands had become the most important commercial nation in Western Europe, and arguably in the world. The French fiscal administrator Jean-Baptiste Colbert, in his report to the king in the Council of Commerce in 1664, noted that "France does not have at present two hundred seaworthy ships in her port; in 1658 the Dutch had sixteen thousand." This superiority in naval trading ability, according to Colbert, allowed the Dutch to take profits from the French economy that, with reforms to the 
internal commerce of France, could and ought to be realized at home (Church, 1969, pp. 82-83). The large fleet of merchants in the Dutch Republic also provided incentives for formal education.

Many commerce related opportunities required literacy and numeracy in their job candidates. Vocational schools were available to train people in everything from literacy to navigation, using maps, and keeping records. Amsterdam, as the commercial center, experienced a threefold rise in merchants by the early seventeenth century (Cook, 2007, p. 58). This large merchant activity kept the Netherlands fully integrated into the international market, which led to regional specialization within the Dutch economy. Transportation along rivers and canals in the Netherlands between Amsterdam and nearby cities transformed the area into one large information network. Newly established newspapers printed commodity prices and exchange rates for both a domestic and international audience (W. Smith, 1984). These phenomena occurred elsewhere in Europe, but none matched the Dutch Republic in volume per capita. Such a large urban commercial base to the Dutch economy expanded the need for literate and numerate people.

It is not enough to say that the Netherlands built more schools and universities per capita than other Western European states because the question still remains as to why they did so. In the Netherlands, literacy rates increased from twelve percent in the sixteenth century to 53 percent in the seventeenth century (Buringh \& Van Zanden, 2009). The reasons for this significant growth in formal education is because the Netherlands developed more inclusive institutions that promoted commerce, created well-integrated market towns and cities which promoted Smithian growth, and created more jobs that required at least a basic formal education in literacy and numeracy.

Between the end of the sixteenth century and the middle of the eighteenth century, the Netherlands had transformed itself into a nation of educated people. Adam Smith observed not long after that Holland had nearly "acquired its full complement of riches, where in every particular branch of business there was the greatest quantity of stock that could be employed in it" (A. Smith, 1776, Book I, p. 199). Dutch society developed further out of the isolated villages of Medieval agrarian self-subsistence: their economy was fully monetized, agricultural production was specialized and bound for the domestic and international market, more people per capita were working in wage labor, more "middle men" working in trade, and finally, there were many opportunities available that required understanding the world beyond just one's village and plot of land.

The combination of these phenomena created more incentives in society to acquire literacy and numeracy skills, and these opportunities and incentives were not limited to the upper-classes of society. Seventeenth century schooling became a common feature of life for children up and down the social strata, including remote rural areas. In rural Drenthe, for example, an ordinance of 1630 established funds to pay for primary schooling for every child. By the end of the eighteenth century, literacy rates in the province were around eighty percent of the population (De Vries \& Van Der Woude, 1997, p. 170). Even orphanages made efforts to provide their children with the necessary skills to work in the Dutch job market. One religious orphanage in Amsterdam argued for teaching literacy and numeracy skills to their wards before sending them to apprenticeships, for if not, "once they become skilled in their craft they still do not possess the capacity to keep records of that which they make, buy, or sell” (G. A. Amsterdam, Part. Arch. 343, no. 8; quoted from De Vries \& Van Der Woude, 1997, p. 694). This passage gives insight to how modern the Dutch job market and economy had become by the mid-seventeenth century.

The comparison between the Habsburg Spanish Empire and Dutch Republic in the early modern era provides two interesting and diverging cases for why growth in education occurred, or did not. The following two examples will again juxtapose the growth in literacy rates as a result of extractive versus inclusive institutions. France experienced more development in formal education throughout its territories in the early-modern period than did Habsburg Spain, yet many of the extractive institutional characteristics of the latter were present in France as well. France throughout its Ancien Regime, experienced average growth in literacy rates for Western Europe. By the mid-seventeenth century, England's literacy rates were more than 50 percent their population. France did not experience this level of literacy until the latter half of the nineteenth century.

\section{France and England}

The Annales School historian Pierre Goubert characterized early-modern France as one where the peasant majority of French society remained fixed to their land and status. "Nineteen and a half out of twenty million people remained bound up to the land, plot, hut cottage, or quartier where they grew up. Old France is characterized not by unrest, social mobility and popular migration, but by sedentariness" (Goubert, 1973, p. 43). Further analysis by Collins $(1991,1995)$ has shown Goubert's view to exaggerate the extent to which peasants were sedentary. Despite this more nuanced and accurate understanding of early-modern France, it was still a 
society where the majority of people were overtaxed rural peasants with few to no options for social mobility. Goubert may have exaggerated geographical mobility among the peasants, but not social or economic mobility.

To understand the growth and spread of formal education in early-modern France requires understanding its fiscal problems, its lack of cultural and economic integration, its large territory and population, and the lack of economic incentives for families to have their children spend time away from work, learning to read and write. The development of formal education in France is by no means uniquely poor in the seventeenth century. By any world comparison of the time, France had some of the best and most advanced education in the pre-industrial period. It had a far more literate society than Habsburg Spain and, like the German Territories, remained around the average for Western Europe prior to the French Revolution. Yet, the corrupt institutions and poor social capital that led to the French Revolution were also the reason the state maintained a large, impoverished, uneducated, and despised peasantry.

The Nineteenth Century Demographer Louis Maggiolo examined the Ancien Regime marriage registers and concluded that 75 percent of people in France in the late seventeenth century could not sign their names (Fleury \& Valmary, 1957). This figure matches well with Buringh and Van Zanden's (2009) conclusion that in the seventeenth century, roughly 71 percent of the population were illiterate. The historical development of extractive institutions, such as a patrimonial absolutist state, help explain why roughly 14 million people out of 20 million remained illiterate throughout the Ancien Regime.

Throughout the sixteenth and seventeenth centuries, education in France was enmeshed in religious struggles and wars between Protestants and Catholics. Both Protestants, such as the Huguenots, and Catholics, such as the Jesuits, believed education was vital to the moral and political development of the nation. To check the increasing progress of Protestantism, the Jesuits formed in response to what they considered a battle for the will of the individual and the nation. The Jesuits, which Durkheim described as an "army," played an important role in shaping educational thought and the structure of teaching in France between the late sixteenth and mid-eighteenth centuries (Durkheim, 2006, p. 232). These struggles ended in Catholicism emerging the dominant religion of the state, and, significantly, the outward migration of many prominent French Protestants to the Netherlands and England. Following the assassination of Henry IV in 1610, the remainder of the century had strong conservative Catholic control of French education under Louis VIII and his long-reigning successor Louis XIV. Struggles within state and between states shaped the institutional development of the Ancien Regime.

Continental wars and competition for hegemony left the French state in constant need of revenue. The two main sources came from heavy taxation of the peasantry and the sale of public offices as private property. As the seventeenth century progressed, the consequences of a growing reliance on these two sources of revenue meant that social mobility was unattainable for the majority peasant class, and those who held tenure in public offices were politically opposed to reforms that could have reduced transaction costs in the economy and made it more efficient and dynamic. Like in Habsburg Spain, patrimonial absolutist bureaucracies meant that instead of a meritocratic selection of candidates, offices in government and military commands went to those who could afford to buy them. As the state had need for more revenue, they created new administrative posts and sold them as private property with lifetime tenures. People were willing to pay several years' worth of their income to invest in these posts, which then allowed them to extract fees and taxes from the poor. As this bureaucracy expanded, so did its inefficiencies, which raised transaction costs within the regional economy and failed to integrate the national economy as a whole.

Early-modern France had weak cultural and economic integration among the various territories. The state remained divided into many regional economies, with populations that spoke different dialects, and an inability or disincentive to transport goods from one region to another. This created disparate growth between social classes and throughout the various regions of the state. The regions connected to international trade expanded, while other sectors remained backwards and cut-off. This lack of economic integration inhibited Smithian growth and endured as a major weakness of the Ancien Regime (Collins, 1995, p. 179). Literacy rates outside Paris reflected these regional differences. Collins (1995, pp. 194-195) summarized the cultural and linguistic regional differences as follows:

"Vast areas of France did not speak French in the eighteenth century. In western Brittany, everyone spoke Breton; in the Midi, people spoke dialects, some of which, like Auvergnat, might be considered separate languages. Along the Mediterranean, many country people spoke Occitan or Provencal; in the Alps, it would be Italian; in the Pyrenees, Basque, Catalan, or Spanish; in the north, many spoke Flemish or Picard; in the east, all of Alsace spoke a German dialect. The progress of French came slowly to most of France. The real limits of popular French were the core of the Ile-de-France, the Loire valley, Champagne, western 
Lorrained, southern Picardy, Burgundy, the Lyonnais, and Normandy. Elsewhere, townspeople knew French but the country people often did not. Those who did not know how to speak French, of course, had not learned how to read it."

Thus, in the last decades before the French Revolution, France had begun to modernize its state but these reforms came too late and had too large a task to change the institutions that had developed since the Middle Ages.

The degree to which education did not penetrate into the peasant majority of French society is still evident in the nineteenth century, and can provide limited insights into peasant attitudes toward education that may have been present two centuries earlier. The reforms of the French Revolution improved the institutional structure of the country somewhat, but the path to institutional change can take a long time to develop. One of the largest tasks of nineteenth century France was to mitigate the issues that kept literacy rates from developing in the seventeenth century, that is, unite the country economically, culturally, and linguistically. According to Eugene Weber's excellent study of nineteenth century France:

"In 1863, . 8 8,381 of France's 37,510 communes spoke no French: about a quarter of the country. The Ministry of Public Instruction found that 448,328 of the 4,108,427 schoolchildren (ages seven to thirteen) spoke no French at all, and that another 1,490,269 spoke or understood it but could not write it" (E. Weber, 1976, p. 67).

In other words, nearly half of school-aged children struggled with the French language and many did not speak it at all. E. Weber's study found that, by the mid-nineteenth century, literacy in France had improved little from the rates in the seventeenth century, and he provided an interesting reason for why they eventually did begin to increase. When attitudes improved towards schooling for girls, the next generation of children had mothers who could speak French to their children if they chose. (E. Weber, 1976, pp. 309-310).

Along with the unification of France as a more homogenous cultural and linguistic territory, the other important change that improved formal education was a change in social solidarity. The cultural chasm that developed in the sixteenth and seventeenth century created a dichotomy in French society between the minority of educated elite, and the masses of illiterate peasants still living according to oral tradition and local village, self-subsistence agriculture. This gulf between rich and poor, educated and uneducated, became a rigid structure in the Ancien Regime that resulted in little social mobility. This structure, comparable to Spain, lacked a growing middle class bridged between the two ends of the social strata. As will be shown in the final example below, it was exactly this "middling sort" in English society that contributed to growing literacy rates throughout the early-modern period.

Early-modern England experienced a large expansion in formal education between the mid-sixteenth and mid-seventeenth centuries. Estimated literacy rates increased in this period from 16 percent in the sixteenth century, to 53 percent by the middle of the seventeenth century, more than double the average for nation states in Western Europe (Buringh \& Van Zanden, 2009). Like the Netherlands, there was an expansion of schools built during this period, and access to them for much of the English social strata. To understand why literacy rates improved so much in less than a century, requires looking at the underlying institutional framework of English society to find what features were conducive to such an expansion.

In Tocqueville's study of the French Ancien Regime, he recorded his research into the Medieval structure of legal institutions in France, Germany, and England. He wrote that "the further I went in my research, the more astonished I was by the remarkable similarity of the laws in these various countries, and the more I marveled at the way in which such different people, who had so little to do with one another, had been able to equip themselves with such similar institutions" (Elster, 2011, p. 23). Similarities existed between the French and English statebuilding process from the Middle Ages to the reigns of the Stuarts and Louis XIV, but there were also many important differences in English society that shaped its future development.

The aforementioned has shown how the failure in France to unite the country culturally and linguistically left lasting difficulties in the growth and development of formal education. Bloch, in his study of feudalism, noted that in fourteenth century "England there was the common law, almost untouched by regional exceptions; in France the vast medley of regional customs" (Bloch, 1962, p. 448). In England, both the Common Law, and a Crown responsible to Parliament, had been established in the thirteenth century (Ertman, 1997; Fukuyama, 2011; Sacks, 1994). The wool trade supported a nascent middle class of townsmen, traders, and yeoman, and roughly half the population worked for wages by the fourteenth century. An important contrast to French society was that in England there was "no legally privileged nobility" (MacFarlane, 1987, p. 149). The combination of the Common Law, Parliament, and a fairly open social structure played an important role in the institutional 
development of English society.

John Fortescue, a fifteenth century statesman who spent time in both countries, argued that England differed from France because in the latter, the "king may rule his people by such laws as he makes himself and therefore he may set upon them taxes and other impositions, such as he wills himself." In the former, the "king may not rule his people by other laws than such as they assent to and therefore he may set upon them no impositions without their own assent" (Fortescue, 1997). To Fortescue, the strength of the English state came from the high degree of economic, political, and legal interaction within communities. England had a large middle class free to act for the good of their communities which meant that there was a large number of people able to sit on juries and judge the facts of a law case. In France, Fortescue argued, the wealthy and poor were not neighbors and lacked a social solidarity with one another.

The strength of the middle class in English towns and cities is rooted in political developments that occurred long before early-modern times. In feudal times, when the king was not powerful enough to offer protection across the English territory, the poor sought the protection of great lords in exchange for land and labor. With the rise of towns and cities people left these feudal contracts to live as free individual laborers. According to Adam Smith, the lords "despised" these new urban classes and were in return "hated and feared." What eventually gave political strength to the urban middle class, and protected them from wealthy lords, was that "The king hated and feared them too; but though perhaps he might despise, he had no reason either to hate or fear the burghers. Mutual interest, therefore, disposed them to support the king, and the king to support them against the lords" (A. Smith, 1776, p. 499). Cities and the middle class in England did not just develop from trade and economic growth; it also required important political developments.

Smith went on to argue that the subsequent growth of cities, commerce, and manufacturing, was the "cause and occasion of the improvement and cultivation of the country" (A. Smith, 1776, p. 515). By the reign of Elizabeth in last half of the sixteenth century, England was experiencing massive population growth, had settled post-Reformation tensions, and according to Smith, the English legislature was "attentive to the interests of commerce and manufacturers" (A. Smith, 1776, p. 517). Compared to the Spanish Empire, whose aspiring wealthy held commerce in disdain, English society towards the end of the sixteenth century had a much better institutional framework to incentivize commerce, business, and manufacturing.

At the beginning of Elizabeth's reign in 1558, England had a population of roughly three million inhabitants. A century later the population was 5.5 million. London went from a city of less than 60,000 inhabitants in 1520 to 400,000 by 1650 . Toward the end of the sixteenth century, Frederick I, Duke of Württemberg, described London as a "large, excellent, and mighty city of business...most of the inhabitants are employed in buying and selling merchandize, and trading in almost every corner of the world..." (Rye, 1865, p. 7). By the end of the seventeenth century it reached about 575,000 inhabitants (R. M. Smith, 1978, pp. 207, 224). Such a rapid rise in population meant that Elizabethan England had larger market towns and cities; it also meant it had a nation full of children, many more of whom would learn their letters from a formal education than previous generations.

Formal education played an important role in social mobility in early-modern England. Sir Thomas Smith, who worked as an English Ambassador in France, believed a major difference between France and England concerned the latter's opportunities for social mobility. Commenting on the English yeomanry, he wrote that they:

"confess themselves to be no gentlemen, but give the honour to al which be or take upon them to be gentlemen, and yet they have a certain preheminence and more estimation than laborers and artificers, and commonly live welthilie, keepe good houses, and do their business, and travaile to acquire riches: these be (for the most part) fermors unto gentlemen, which with grasing, frequenting of markettes, and keeping servauntes not idle as the gentlemen doth, but such as get both their owne living and parte of their maisters: by these means doe come to such wealth, that they are able and daily doe buy the landes of unthrifty gentlemen, and after setting their sonnes to the schoole at the Universities, to the lawe of the Realme, or otherwise leaving them sufficient landes whereon they may live without labour, do make their saide sonnes by those meanes gentlemen" (T. Smith, 1906).

Beginning in the last half of the sixteenth century, formal education began to expand all over England. Part of the trend was an increase in the gentry class and the widespread desire to send their children to be educated at Oxford, Cambridge, and the Inns of Court. Power and influence in society began to depend more on learning than it did on the traditional avenues of birth and military honor and expertise (Levy, 1982). But education did not limit itself to the sons of the gentry. Many of the new schools built in Elizabethan England came from wealthy donors and were intended for everyone to attend. 
Beginning in the last half of the sixteenth century, many wealthy merchants, lawyers, and landowners, often self-made in a successful career, left funds in their wills to establish schools and public libraries, so that the next generation may learn the necessary skills to apprentice as merchants, in business, as clerks, navigators, surveyors, map readers, teachers, or join the new Church of England. For example, in 1599, the cloth merchant Peter Blundell of Tiverton, left in his will the funds to "erecte and build a faier School Houfe to conteyne for the Place for teaching." It "shall be forever a Free Scholl and not a Schole of Exaction." In addition, he left "the Some of twoe thousand Powndes" to establish scholarships for his students to "the Universities of Oxford or Cambridge or in both for ever" (Incledon, 1792, pp. 33, 37, 44).

The lawyer Richard Cholmeley helped found Highgate School in 1565. The Bishop of Durham James Pilkington established Rivington Grammar School in 1566 "for a continual bringing up, teaching and learning of boys and youth of the village or hamlet of Rivington and neighbouring hamlets" (Kay, 1931, p. 10). The London brewer Richard Platt started a free grammar school and almshouse in 1599 (p. 1908). Sir John Leman, after a merchant and civil service career in London, established a primary school for poor children in his hometown of Beccles, Suffolk in 1631. He wanted poor children to have opportunities to learn reading, writing, and numeracy (Lawson \& Silver, 1973, p. 106). Though schooling expanded between the ascension of Elizabeth I and the English Civil War, many poor families still did not send their children to school, or if they did, it was for a brief time and then forgotten. That said, the avenue for social mobility did exist.

Sir Edmund Saunders began his life begging on the street, but after primary schooling and a legal education, rose to the rank of Lord Chief Justice of the King's Bench. Sir Isaac Newton, whose father was illiterate, became Europe's most prominent scientist (Thomas, 2009, pp. 4, 29). William Petty, writing a letter of advice to Samuel Hartlib, believed that formal education should

"be seriously studied and practised by the best and abler persons. That all Children of above seven yeares old may be presented to thi kind of Education, none being to be excluded by reason of the poverty and unability of their Parents, for hereby it hath come to passe, that many are now holding the Plough, which might have beene made fit to steere the State. Wherfore let such poor children be imployed on works wherby they may earne their living, equall to their strength and understanding, and such as they may performe as well as elder and abler person..." (Petty, 1648, p. 4).

Expansions of formal education often accompany growth in a population, but in the Middle Ages and early-modern era, an expansion in the former only occurred if a conducive institutional structure was already in place. For a society to lift itself out of the Malthusian Trap requires sustained economic growth, and historically, the first societies to achieve this, England and the Netherlands, did so because they had traditions of inclusive institutions and a growing formally-educated middle-class. Efficient institutions that upheld the rule of law and the protection of property rights allowed the scale of commerce to expand, provided for more people living in market towns and cities, and made the skills and knowledge learned from formal education more beneficial.

\section{Conclusion}

What are the historic reasons for growth or expansion in formal education in a society? A culture of literacy has its roots in the formal institutions that bind a state together: the development of a centralized state, a legal system, and religious or spiritual beliefs. In many instances, the literate culture that develops may be completely different from the vernacular(s) spoken in the region. The grammar of ancient written Chinese was quite different from the grammar in the vernacular; The written hieroglyphs of priests and scribes in Ancient Egypt varied considerably from the vernacular; The Latin and French used in church and state in Medieval England differed from the vernacular of the village farmer. Often it requires a Chaucer or a Pushkin to make the written vernacular popular.

State-building requires a monopoly on the use of force and a system of law to adjudicate disputes. A state monopoly on force requires the members of society not resort to violence, or revenge justice, to solve the problems of cooperation and competition. Institutions shape how we live in our societies, and they also shape how we educate our children to compete and cooperate in that society. In Medieval Europe, the many books of etiquette from The Book of Hours to On Civility in Children were written as guides to the cultivation of good manners and conduct in a civilized society. Much like how the etiquette of a gentleman and lady began as courtly manners and slowly spread to the middle class and lower classes of society throughout the course of modernization, so too did literacy spread in analogous fashion.

Literacy began in state, legal, and religious institutions, and later spread throughout the middle-classes of European society as they emerged and prospered. The degree to which literacy spread in early-modern society depended on the institutional traditions already present. The best answer as to why England and the Netherlands 
developed literate populations at a faster rate than other European states, prior to the Industrial Revolution, was due to their precocious development of modern political institutions. As developing states in the twenty-first century look to achieve economic growth and the human capital to supply it, they may look to the historic lessons of human capital development, and understand the need for inclusive institutions that promote commerce, and uphold the rule of law and private property. These are the foundations from which sustained growth is derived, and subsequently provide important incentives to invest in formal education.

\section{References}

Acemoglu, D., Johnson, S., \& Robinson, J. (2005). The Rise of Europe: Atlantic Trade, Institutional Change, and Economic Growth. American Economic Review, 95(3), 546-579. https://doi.org/10.1257/0002828054201305

Allen, R. C. (2003). Progress and Poverty in Early Modern Europe. Economic History Review, 3, 403-443. https://doi.org/10.1111/j.1468-0289.2003.00257.x

Armytage, W. H. G. (1964). Four Hundred Years of English Education. London: Cambridge University Press. https://doi.org/10.2307/367161

Bloch, M. (1962). Feudal Society. London: Routledge \& Kegan Paul Ltd.

Bowen, J. (1975). A History of Western Education (Volume Two, Civilization of Europe, Sixth to Sixteenth Century). London: Methuen \& Co Ltd.

Bowen, J. (1981). A History of Western Education (Volume Three, The Modern West, Europe, and the New World). London: Methuen \& Co Ltd.

Buringh, E., \& Van Zanden, J. (2009). Charting the "Rise of the West": Manuscripts and Printed Books in Europe, A Long-Term Perspective from the Sixth through Eighteenth Centuries. The Journal of Economic History, 69(2), 409-445. https://doi.org/10.1017/S0022050709000837

Carey, S. (2000). Science Education as Conceptual Change. Journal of Applied Developmental Psychology, 21(1), 13-19. https://doi.org/10.1016/S0193-3973(99)00046-5

Casey, J. (1999). Early Modern Spain: A Social History. London: Routledge.

Church, W. F. (1969). The Impact of Absolutism in France: National Experience under Richelieu, Mazarin, and Louis IV. New York: John Wiley and Sons Inc.

Collins, J. B. (1991). Geographic and Social Mobility in Early-Modern France. Journal of Social History, 24(3), 563-577. https://doi.org/10.1353/jsh/24.3.563

Collins, J. B. (1995). The State in Early Modern France. Cambridge: Cambridge University Press. https://doi.org/10.1017/S0026749X0001708X

Cook, H. J. (2007). Matters of Exchange: Commerce, Medicine, and Science in the Dutch Golden Age. New Haven: Yale University Press. https://doi.org/10.12987/yale/9780300117967.001.0001

De Pleijit, A. M., \& Van Zanden, J. (2016). Accounting for the "Little Divergence": What Drove Economic Growth in Pre-Industrial Europe, 1300-1800? European Review of Economic History, 20, 387-409. https://doi.org/10.1093/ereh/hew013

De Vries, J., \& Van Der Woude, A. (1997). The First Modern Economy: Success, Failure, and Perseverance of the Dutch Economy, 1500-1815. New York: Cambridge University Press. https://doi.org/10.1017/CBO9780511666841

Dodgshon, R. A., \& Butlin, R. A. (1978). An Historical Geography of England and Wales. London: Academic Press. https://doi.org/10.4200/jjhg1948.31.189

Durkheim, E. (2006). Selected Writings on Education (Vol. II, The Evolution of Educational Thought: Lectures on the Formation and Development of Secondary Education in France). London: Routledge. https://doi.org/10.4324/9781315020594

Eisner, M. (2003). Long-Term Historical Trends in Violent Crime. Crime and Justice, 30, 83-142. https://doi.org/10.1086/652229

Elias, N. (1978). The Civilizing Process. New York: Urizen Books.

Elliott, J. H. (1955). The King and the Catalans, 1621-1640. The Cambridge Historical Journal, 11(3), 253-271. https://doi.org/10.1017/S1474691300003061 
Ertman, T. (1997). Birth of the Leviathan, Building States and Regimes in Medieval and Early Modern Europe. Cambridge: Cambridge University Press. https://doi.org/10.1017/CBO9780511529016

Eskelson, T. C. (2020). How and Why Formal Education Originated in the Emergence of Civilization. Journal of Education and Learning, 9(2), 29-47. https://doi.org/10.5539/jel.v9n2p29

Ferguson, N. (2018). The Square and the Tower: Networks and Power, From the Freemasons to Facebook. New York: Penguin Books.

Findlay, R., \& O’Rourke, K. H. (2007). Power and Plenty: Trade, War, and the World Economy in the Second Millennium. Princeton New Jersey: Princeton University Press. https://doi.org/10.1515/9781400831883

Fleury, M., \& Valmary, P. (1957). Les progrès de l'instruction élémentaire de Louis XIV à Napoléon III, d'après l'enquête de Louis Maggiolo (1877-1879). Population, 12(1), 71-92. https://doi.org/10.2307/1525321

Fortescue, J. (1997). Cambridge Texts in the History of Political Thought. In L. Shelley (Ed.), Sir John Fortescue: On the Laws and Governance of England (pp. 157-159). Cambridge Texts in the History of Political Thought. Cambridge: Cambridge University Press. https://doi.org/10.1017/CBO9781139170512.011

Fukuyama, F. (1995). Trust: Human Nature and the Reconstitution of Social Order. New York: Touchstone Books.

Fukuyama, F. (2011). The Origins of Political Order: From Pre-human Times to the French Revolution. London: Profile Books.

Geary, D. C. (2007). Educating the Evolved Mind: Conceptual Foundations for an Evolutionary Education Psychology (pp. 1-100). Information Age Publishing.

Gleeson-White, J. (2011). Double Entry: How the Merchants of Venice Shaped the Modern World and How their Invention Could Make or Break the Planet. Sydney: Allen \& Unwin.

Goubert, P. (1973). The Ancien Regime: French Society 1600-1750 (Translated by Steve Cox). George Weidenfeld and Nicholson Ltd.

Hirschman, A. O. (1977). The Passion and the Interests: Political Arguments for Capitalism before its Triumph. Princeton, N.J.: Princeton University Press. https://doi.org/10.1515/9781400848515

Houston, R. A. (1988). Literacy in Early Modern Europe: Culture and Education, 1500-1800. London: Longman.

Incledon, B. (1792). Donations of Peter Blundell (Founder) and Other Benefactors to The Free Grammar School at Tiverton. Exeter: E. Grigg.

Jewell, H. M. (1998). Education in Early Modern England. London: MacMillan Press Ltd. https://doi.org/10.1007/978-1-349-27233-4_5

Kagan, R. L. (1974). Students and Society in Early Modern Spain. Baltimore: John Hopkins University Press.

Kay, M. M. (1931). The History of Rivington and Blackrod Grammar School. Manchester: Manchester University Press.

Lachmann, R. (1987). From Manor to Market: Structural Changes in England, 1536-1640. Madison: The University of Wisconsin Press.

Lancy, D. F. (2010). Learning from nobody: The Limited Role of Teaching in Folk Models of Children's Development. Childhood in the Past, 3, 79-106. https://doi.org/10.1179/cip.2010.3.1.79

Lancy, D. F. (2012). Ethnographic Perspectives on Cultural Transmission/Acquisition (pp. 1-51). In Paper Prepared for the School of American Research. Santa Fe, Advanced Seminar: Multiple Perspectives on the Evolution of Childhood.

Lancy, D. F. (2016). Teaching: Natural or Cultural? In D. Berch \& D. Geary (Eds.), Evolutionary Perspectives on Education and Child Development. Heidelberg: Springer. https://doi.org/10.1007/978-3-319-29986-0_2

Lawson, J., \& Silver, H. (1973). A Social History of Education in England. London: Methuen \& Co Ltd. https://doi.org/10.4324/9781315887951

Levy, F. J. (1982). How Information Spread Among the Gentry, 1550-1640. Journal of British Studies, 21(2), 11-34. https://doi.org/10.1086/385788

MacCulloch, D. (2003). The Reformation: A History. New York: Penguin Books. 
MacFarlane, A. (1978). The Origins of English Individualism: The Family, Property, and Social Transition. New York: Cambridge University Press.

MacFarlane, A. (1987). The Culture of Capitalism. Oxford: Basil Blackwell.

Maddison, A. (2003). The World Economy: Historical Statistics. Development Centre Studies, OECD Publishing, Paris. https://doi.org/10.1787/9789264104143-en

Maynes, M. J. (1985). Schooling in Western Europe: A Social History. New York: State University of New York Press.

Morris, I. (2015). Foragers, Farmers, and Fossil Fuels: How Human Values Evolve. Princeton: Princeton University Press. https://doi.org/10.1515/9781400865512

North, D. C. (1981). Structure and Change in Economic History. New York: W.W. Norton \& Company. https://doi.org/10.1177/003232928201100416

North, D. C. (1990). Institutions, Institutional Change, and Economic Performance. Cambridge: Cambridge University Press. https://doi.org/10.1017/CBO9780511808678

North, D. C. (2005). Understanding the Process of Economic Change. Princeton N.J.: Princeton University Press. https://doi.org/10.1515/9781400829484

North, D. C., \& Thomas, R. P. (1973). The Rise of the Western World: A New Economic History. London: Cambridge University Press. https://doi.org/10.1017/CBO9780511819438

O'Day, R. (1982). Education and Society 1500-1800: The Social Foundations of Education in Early Modern Britain. Essex: Longman Group Limited. Retrieved from https://lib.ugent.be/catalog/rug01:000951507

Page, W. (1908). A History of the County of Hertford (Volume 2, ed.). London, British History Online. Retrieved from http://www.british-history.ac.uk/vch/herts/vol2

Petty, W. (1648). The Advice of W.P. to Mr. Samuel Hartlib for the Advancement of fome particular Parts of Learning. London: Printed Anno Dom.

Pinker, S. (2011). The Better Angels of our Nature: Why Violence Has Declined. New York: Penguin Books.

Pollock, F., \& Maitland, F. W. (1952). The History of English Law (Vol. 11, 2nd ed.). Cambridge: Cambridge Univ. Press.

Rye, W. B. (1865). England as Seen by Foreigners in the Days of Elizabeth and James The First. London: John Russell Smith, SOHO Square.

Sacks, D. H. (1994). The Paradox of Taxation: Fiscal Crises, Parliament, and Liberty in England, 1450-1650. Ch1. In T. H. Philip \& N. Kathryn (Eds.), Fiscal Crises, Liberty, and Representative Government: 1450-1789. Stanford: Stanford University Press.

Smith, A. (1776/1999). The Wealth of Nations Books I-III (Edited by Andrew Skinner). London: Penguin Group.

Smith, R. M. (1978). Population and its Geography in England 1500-1730. Ch 8. In R. A. Dodgshon \& R. A. Butlin (Eds.), An Historical Geography of England and Wales. London: Academic Press. https://doi.org/10.4200/jjhg1948.31.189

Smith, T. (1906). De Republica Anglorum: A Discourse on the Commonwealth of England (Edited by L. Alston). Cambridge: Cambridge University Press.

Smith, W. D. (1984). The Function of Commercial Centers in the Modernization of European Capitalism: Amsterdam as an Information Exchange in the Seventeenth Century. The Journal of Economic History, 44(4), 985-1005. https://doi.org/10.1017/S0022050700033052

Spufford, M. (1995). Literacy, Trade and Religion in the Commercial Centres of Europe. In K. Davids, C. S. Lucassen \& J. A. M. Mirrored (Eds.), The Dutch Republic in European Perspective. Cambridge University Press.

Stephens, W. B. (1990). Literacy in England, Scotland, and Wales, 1500-1900. History of Education Quarterly, 30(4), 545-571. https://doi.org/10.2307/368946

Strayer, J. (1970). On the Medieval Origins of the Modern State. Princeton, N.J: Princeton University Press.

Thomas, K. (2009). The Ends of Life: The Road to Fulfilment in Early Modern England. Oxford: Oxford University Press. 
Tilly, C. (1985). War Making and State Making as Organized Crime. Chapter. In B. E. Peter, R. Dietrich \& S. Theda (Eds.), Bringing the State Back In (pp. 169-191). Cambridge: Cambridge University Press. https://doi.org/10.1017/CBO9780511628283

Tocqueville, A. (2011). The Ancien Regime and the French Revolution (Ed. by Jon Elster., Trans. by Arthur Goldhammer). Cambridge: Cambridge University Press. https://doi.org/10.1017/CBO9780511977114

Weber, E. (1976). Peasants into Frenchmen: The Modernization of Rural France, 1870-1914. Stanford: Stanford University Press.

Weber, M. (2019). Economy and Society (Edited and translated by Keith Tribe). Cambridge: Harvard University Press.

Weber, M. (1930/2005). The Protestant Ethic and the Spirit of Capitalism (Translated by Talcott Parsons). London: Routledge. https://doi.org/10.4324/9780203995808

\section{Copyrights}

Copyright for this article is retained by the author, with first publication rights granted to the journal.

This is an open-access article distributed under the terms and conditions of the Creative Commons Attribution license (http://creativecommons.org/licenses/by/4.0/). 